\title{
Experienced Severity of Imprisonment Among Fathers and Non-Fathers
}

\author{
Joni Reef $\mathbb{D}^{1} \cdot$ Anja Dirkzwager ${ }^{2}$
}

Published online: 30 November 2019

(c) The Author(s) 2019

\begin{abstract}
Objectives Even though $90 \%$ of the prison population is male, fatherhood among prisoners is an overlooked topic. Previous studies suggest that experienced severity of detention is different between fathers and non-fathers in prison because there is a unique deprivation strain related to fatherhood. There are criminological arguments and arguments in the legal context why we need more knowledge on the experience of detention by incarcerated fathers.

Methods We studied longitudinal data of 785 males in pre-trial detention in the Netherlands from the nationwide Prison Project study population: 329 fathers were compared with 456 non-fathers for experienced severity, adjustment patterns (i.e. mental distress and misconduct), and deprivations strains.

Results We found differences between fathers and non-fathers, both in adjustment and deprivation strains. Fathers reported less adjustment problems and different deprivation strains than non-fathers. Missing children during pre-trial detention was associated with depressive behavior $(\beta=0.158, p<0.005)$ and anxiety among fathers $(\beta=0.128, p<0.05)$.

Conclusions Our results underline the importance of designing interventions for fathers in prison and educating sentencers about this topic. Proportional sentencing of fathers in the criminal justice system could only be validated as long as sufficient attention will be paid to their unique deprivation strain, which is, missing their children. During pre-trial detention, care for the child-father relation may not only lead to father's emotional wellbeing during pre-trial detention, but may also lead to strengthened family bonds and children's wellbeing on the long term.
\end{abstract}

Keywords Fathers $\cdot$ Prison $\cdot$ Children of prisoners $\cdot$ Deprivation strain $\cdot$ Adjustment

The majority of the adult incarcerated population are parents (Glaze and Maruschak 2008; Mumola 2000). Many prisoners involuntary fail to stay connected with their family during imprisonment and experience difficulties in reconnecting with their family after release (Arditti 2003, 2005; Apel et al. 2010; Lopoo and Western 2005; Nurse 2009). Parental imprisonment may negatively affect the children and the parents themselves, as well as the extended family. It may thereby harm multiple generations of fragile families and may form an unintended and enduring burden to society (Coley and Coltrane 2007;

Joni Reef

j.reef@law.leidenuniv.nl

1 Institute of Criminal Law and Criminality, Leiden University, Steenschuur 25, 2311 ES Leiden, the Netherlands

2 Netherlands Institute for the Study of Crime and Law Enforcement, Amsterdam, the Netherlands
Fonagy et al. 1994). For these reasons, The Council of Europe advocated for more research on incarcerated parents and their children in their recommendation issued in April 2018 (Council of Europe 2018). The Prison Project was initiated to increase current knowledge on incarceration and its intended and unintended consequences. Important features of the Prison Project are its longitudinal design and its focus on multiple domains, among which family life of incarcerated males, mental health, adjustment and wellbeing of prisoners' family members (Dirkzwager et al. 2018).

The vast majority of knowledge on parenthood in prison is focused on mothers in prison or parents more generally. Studies among women and parents in prison describe various strains that are associated with being a parent in prison. For instance, incarcerated mothers have mentioned the separation of their children as the most stressful aspect of imprisonment. They are insecure about the effects of the detention and the separation from their child on their child's wellbeing, and on the care for their children while they are absent and return to the family after detention (Banauch 
1985; Beckerman 1989; Brownell 1997; Burgess and Flynn 2013; Coll et al. 1998; Dodge and Pogrebin 2001; Enos 1997; Flynn 2014; Henriques 1982) Also after release, mothers still struggle with disruptions in their motherhood (Baldwin 2018).

Empirical research comparing the adjustment patterns of incarcerated mothers and non-mothers showed mixed outcomes. Results of a study conducted by Fogel and Martin (1992), in which they measured depression and anxiety among mothers and non-mothers at two time-points, indicated that both mothers and non-mothers showed elevated levels of anxiety when they entered prison. However, the anxiety level of non-mothers decreased after six weeks, while that of the mothers remained the same. The authors argued that the separation from their children was responsible for this outcome. Contrary, Lindquist and Lindquist (1997) and also Hurley and Dunne (1991) found no support for elevated mental distress among mothers, as compared with non-mothers. In addition, Loper (2006) reported that mothers and non-mothers showed, once in prison, the same adjustment problems. Also, in a recent study of Baldwin and Epstein (2017), mothers described that their 'anxiety' was reduced during imprisonment, as a result of good medical care and regular meals. Previous studies have also described adverse effects associated with being a father in prison, however, to our knowledge, none of these studies has directly compared differences in adjustment to prison life between fathers and non-fathers in a large longitudinal study.

Imprisonment is destructive to father involvement (Dallaire 2007; Dennison et al. 2014; Dirkzwager et al. 2009; Lanskey et al. 2016). In the current male penal system, maintaining family bonds and father-child relations is hindered rather than stimulated (Dyer 2005; Western et al. 2004). While, in general, women's prisons are focused on parenthood, males' prisons are not. Male prison values are characterized by discretion around children. For instance, fathers sporadically talk about their children (Brodsky 1995). Regarding daily practice, previous studies in Australia demonstrate a structural lack of support for fathers in prison (Bartlett and Trotter 2019). It has been argued that the deprivation of support programs and services form a barrier to the continuation of father-child relationships (Bartlett et al. 2018).

Fathers, as compared with non-fathers, may experience unique strains during detention (Bartlett and Trotter 2019; Dennison et al. 2017). Studies on incarcerated fathers show that they can experience additional complications related to their position as a father. Incarcerated fathers are condemned to have contact with their children by telephone and letter or during visitation hours. However, geographical distances, as well as odious visiting conditions and high telephone costs obstruct contact between father and child
(Bartlett and Eriksson 2019; Dennison et al. 2013). Because fathers are often not in a relationship with the mother of their children, it is frequently even more difficult to maintain contact with their children once incarcerated (Magaletta and Herbst 2001). Other studies among incarcerated fathers show that fathers worry about their children not remembering them and about their absence as educators and breadwinners (Arditti 2003; Magaletta and Herbst 2001). Studies examining the role of deprivation factors among mothers have shown that decreased contact with children is a consistent risk factor for adjustment problems in prison (Fogel 1993; Hairston 1991; Houck and Loper 2002; Kruttschnitt and Gartner 2005; Poehlmann 2005). At present, it is still unclear to what extent fatherhood-related characteristics affect men's adjustment to prison life in a positive or negative way.

Fatherhood is a relatively neglected area in the entire criminal justice system in both research and daily practice (Reef and Nieuwbeerta 2016; Reef et al. 2018; Seymour 1998). Although knowledge on the topic is increasing, better understanding of the specific deprivation strains of incarcerated fathers, and how such strains may affect fathers' adjustment to their life in prison is crucial (Dennison et al. 2017). More knowledge on fatherhood in prison will aid the development of appropriate prison-interventions, and may lead to more proportional sentencing of fathers in the criminal justice system (Minson 2017, 2018; Reef and Nieuwbeerta 2016; Reef et al. 2018; Scharff-Smith 2018).

Not only fathers themselves will benefit from more knowledge on unintended consequences of incarceration. Previous studies demonstrated the impact of the absence of incarcerated fathers on their children. Paternal incarceration affects children in many different ways (Geller et al. 2012; Murray and Farrington 2005). Both short term adverse effects, such as failed school careers and reduced social wellbeing were found (Brown et al. 2001; Phillips et al. 2002). In addition, long-term adverse effects, such as mental health problems in adulthood, depression, anxiety, sleeping problems and sadness were confirmed (Johnston and Gabel 1995; Murray and Farrington 2005; ScharffSmith 2014).

Being the first of its kind, the present study compared a group of male prisoners with and without children. The objectives are two-fold. First, we examined the extent to which fathers and non-fathers differ in (a) their perceptions of the severity of their time in prison, (b) the experienced deprivations or 'pains of imprisonment', and (c) their adjustment patterns (both mental distress and misconduct) during pre-trial detention. Second, we examined to what extent fatherhood-related strains affect incarcerated fathers' subsequent adjustment to detention. Data were used from the Prison Project, a nation-wide and longitudinal research 
project examining the development of criminal behavior and life circumstances before, during and after detention in the Netherlands.

\section{Method}

\section{Participants}

The target population of this Prison Project consisted of male prisoners, aged 18-65 years, who were born in the Netherlands, and who entered one of the Dutch pre-trial detention centers between October 2010 and April 2011. At the time of the data collection, the Netherlands had 58 correctional facilities for adult prisoners, of which more than half operated as pre-trial detention centers. Between October 2010 and April 2011, 3981 defendants met the selection criteria and entered a pre-trial detention center in the Netherlands.

Of the 815 respondents that participated in wave 1 and wave 2, 785 men provided information on their fatherhood. We compared characteristics of 329 fathers (i.e. participants who indicated that they have children) to those of 456 detained men who indicated that they never had children (see Table 1). The average age of fathers was 36.5 years, which was significantly higher than the average age of 26.2 of non-fathers. Fathers had more often a romantic partner (78 versus $49 \%$ ) and $58 \%$ of the fathers were living with children in their household before they were imprisoned. Non-fathers were significantly more often second generation immigrants (42 versus $27 \%$ ). Fathers had more often a job than non-fathers (50 versus $38 \%$ ) and were higher educated (10 versus $3 \%)$. There were no differences in lower and secondary education levels. Fathers reported less daily drug abuse before detention than non-fathers (19 versus 29\%). Prior alcohol abuse was not significantly different between fathers and non-fathers $(\mathrm{M}=38 \%)$. Regarding prior criminal behavior experiences, fathers (M $=3.8$ ) had more often been detained than non-fathers $(\mathrm{M}=$ 2.2), but less often for violent crimes, and more often for drug-related crimes.

\section{Procedure}

The baseline measurement took place about 3 weeks after their arrival in pre-trial detention and consisted of a faceto-face interview and a self-administered questionnaire. We approached 2841 defendants. Participation was voluntary and confidential. All participants signed an informed consent form. The vast majority of the incarcerated men that could not be approached had already been released. A total of 1904 of the approached prisoners (67\%) participated in the baseline interview and 1748 (62\%) also completed the questionnaire. Non-response analyses based on registered data of the Dutch Prison Service showed that the characteristics of the respondents were almost identical to those of the total target group of 3981 (Dirkzwager et al. 2018).

The second measurement took place about 3 months after participants' arrival in pre-trial detention. At that time 1275 of the 1904 were still in custody. 1056 respondents from the first measurement were asked to participate again. Of these, 815 prisoners participated and filled out a self-administered questionnaire. In general, the characteristics of respondents of the second measurement in prison and respondents of the baseline measurement were similar (Dirkzwager et al. 2018). The majority of the prisoners (90\%) was still located in a pre-trial detention center at the second wave; a small group of prisoners $(10 \%)$ had been relocated to a prison section, most of the time in the same institution. For the present study we used data of both the first and second wave of the Prison Project.

Table 1 Descriptive statistics of fathers and non-fathers

\begin{tabular}{|c|c|c|c|c|}
\hline Demographic variables & $\begin{array}{l}\text { Fathers } \\
(n=329)\end{array}$ & $\begin{array}{l}\text { Non-fathers } \\
(n=456)\end{array}$ & $X^{2}$ tests & T-tests \\
\hline Age (years) ${ }^{*}$ & 36.5 & 26.2 & & $\mathrm{t}(812)=-15.257, p<0.000$ \\
\hline Romantic partner ${ }^{*}$ & $78 \%$ & $49 \%$ & $X^{2}(1)=64.47, p<0.000$ & \\
\hline Living with child & $58 \%$ & & & \\
\hline Ethnicity/ $2^{\text {nd }}$ gen. immigrants ${ }^{*}$ & $27 \%$ & $42 \%$ & $X^{2}(1)=21.75, p<0.000$ & \\
\hline $\mathrm{Job}^{*}$ & $50 \%$ & $38 \%$ & $X^{2}(1)=12.42, p<0.000$ & \\
\hline Higher education* & $10 \%$ & $3 \%$ & $X^{2}(1)=18.61, p<0.000$ & \\
\hline Detention spells ${ }^{*}$ & 3.82 & 2.16 & & $\mathrm{t}(809)=-4.140, p<0.000$ \\
\hline Experienced severity of detention & 4.89 & 4.87 & & $\mathrm{t}(739)=-0.109, p<0.913$ \\
\hline
\end{tabular}

*Indicates $p<0.00$ 


\section{Measures}

At wave one and two, respondents filled out a selfadministered questionnaire in their cells. To asses fatherhood, we asked respondents to complete a dichotomous survey question; “do you have children?". Based on prior empirical research on predictors of adjustment in prison we also examined the following socio-demographic characteristics, measured at the first wave when the prisoners were in pre-trial detention for about 3 weeks: age, ethnicity, educational level, having a partner, having a paid job, number of previous offenses at the time of arrest, type of offense, prior prison experiences, alcohol misuse and daily drug use (Dirkzwager and Nieuwbeerta 2018). The non-response group for this outcome variable was not significantly different from the response group regarding: age, educational level, having a partner, having a paid job, type of offense. The non-response group was however more often a second generation immigrant.

\section{Perceived Severity and Deprivation Strains}

To assess inmates' experienced severity of their detention, inmates were asked to indicate on a 7-point scale how severe they experienced their time in detention $(1=$ not severe at all, to $7=$ very severe). To evaluate the impact of separate deprivation strains, respondents were also asked to rate on a five-point Likert scale $(0=$ not relevant in my situation (i.e. I don't have a partner, I don't have children); $1=$ not at all; $5=$ very much) to what extent they missed the following persons or things during their detention: (1) my partner, (2) my child(ren), (3) my parents, (4) other family members, (5) my friends and acquaintances, (6) my pet(s), (7) my house, (8) my own things, (9) my own food, (10) money, (11) work, (12) intimacy, (13) sex, (14) drugs, (15) alcohol.

\section{Adjustment Problems: Mental Distress}

To explore the level of mental distress we used the Brief Symptom Inventory (BSI) at both waves (De Beurs and Zitman 2006; Derogatis 1993). The BSI is a frequently used screening instrument and standardized psychological selfreport symptom scale that has often been used in prison samples (Dirkzwager and Nieuwbeerta 2018; Lindquist 2000). The BSI consists of 53 items and detainees could score on a five-point scale $(0=$ none; $4=$ very much) how much they experienced each symptom in the last week. We computed scores on the following subscales: Somatization, Obsession Compulsion, Interpersonal Sensitivity, Depression, Anxiety, Hostility, Phobic Anxiety, Paranoid Ideation and Psychoticism. In addition, the total score on the BSI can be used as an indication for the overall level of psychological distress. Each BSI scale was calculated by summing the scores of the items and dividing this by the number of items. Good convergent and construct validity, test-retest reliability and internal consistency has been reported for the BSI (De Beurs and Zitman 2006; Derogatis 1993).

\section{Adjustment Problems: Misconduct}

Self-reported misconduct in prison was measured at both waves. In the questionnaire, inmates were asked whether they had misbehaved since their arrival in pre-trial detention (for wave 1) and since the first wave (for wave 2). More specifically, inmates were asked whether they had been (1) verbally aggressive to a fellow detainee, (2) physically aggressive to a fellow detainee, (3) verbally aggressive to a staff member, and (4) physically aggressive to a staff member. Two dichotomous variables were constructed: any verbal or physical aggressive behavior towards fellow prisoners $(0=$ no, $1=$ yes $)$; any verbal or physical aggressive behavior towards staff members $(0=$ no, $1=$ yes $)$.

\section{Data Analyses}

We first compared fathers with non-fathers groups for demographic characteristics. Subsequently we compared two-wave adjustment problem patterns between fathers and non-fathers with t-tests: two-wave mean scores on the BSI and two-wave pains of pre-trial detention of the fathers and non-fathers. Also, we analyzed with multivariate regression analyses whether fathers and non-fathers differed with respect to mental health problems and interpersonal aggressive behavior in prison. Lastly, we focused on the fathers to see if their unique strain of missing their children is associated with mental distress by performing multivariate regression analyses. BSI scales at the second wave were the dependent variables in separate regression analyses; the 'I miss my child' variable was the independent variable in all regression analysis. We adjusted for age, ethnicity, educational level, having a job and having a partner.

\section{Results}

Fathers and non-fathers did not differ in their overall ratings of the detention severity: both groups rated 4.8 on a 7-point scale. However, fathers and non-fathers did show different patterns regarding the experience of separate deprivation strains. They differed significantly with respect to 8 out of 14 ('I miss my child' not included) deprivation strains (see Fig. 1). Compared to non-fathers, fathers reported higher scores for missing intimacy $(\mathrm{t}(731)=-3.76, p<0.000)$, 
Fig. 1 Differences in subjective severity of deprivation strains between fathers and non-fathers. Note. Deprivation strains indicated with $*$ were all statistically significant different $(p<0.001)$. The $\mathrm{t}$-values were: -3.76 for intimacy, -4.79 for own house, -7.74 for partner, 2.58 for money, 5.71 for parents, 2.98 for friends, -2.83 for pets, and 4.67 for drugs
Table 2 Fathers and non-fathers adjustment patters three weeks and 3 months after arrival in detention

\begin{tabular}{|c|c|c|c|c|c|c|c|c|c|}
\hline & \multicolumn{3}{|l|}{ Fathers } & \multicolumn{3}{|l|}{ Fathers } & \multicolumn{3}{|c|}{ Non-fathers } \\
\hline & \multicolumn{3}{|c|}{3 weeks in detention } & \multicolumn{3}{|c|}{$\begin{array}{l}3 \text { months in } \\
\text { detention }\end{array}$} & \multicolumn{3}{|c|}{$\begin{array}{l}3 \text { months in } \\
\text { detention }\end{array}$} \\
\hline & $N$ & $M$ & $S D$ & $N$ & $M$ & $S D$ & $N$ & $M$ & $S D$ \\
\hline \multicolumn{10}{|l|}{ Adjustment IM } \\
\hline \multicolumn{10}{|l|}{ Mental distress (BSI) } \\
\hline Depression & 324 & 0.86 & 1.00 & 320 & 0.84 & 0.78 & 465 & 0.88 & 0.88 \\
\hline Anxiety & 323 & 0.69 & 0.90 & 321 & 0.51 & 0.59 & 466 & 0.61 & 0.68 \\
\hline Hostility & 324 & 0.62 & 0.83 & 321 & 0.37 & 0.48 & 463 & 0.52 & 0.64 \\
\hline Somatic complaints & 324 & 0.57 & 0.83 & 321 & 0.46 & 0.61 & 465 & 0.47 & 0.63 \\
\hline Cognitive problems & 323 & 0.78 & 0.90 & 320 & 0.59 & 0.63 & 464 & 0.69 & 0.79 \\
\hline Interpersonal sensitivity & 323 & 0.57 & 0.84 & 320 & 0.32 & 0.49 & 465 & 0.45 & 0.66 \\
\hline Phobic anxiety & 323 & 0.42 & 0.73 & 320 & 0.23 & 0.42 & 465 & 0.29 & 0.54 \\
\hline Paranoid ideation & 323 & 1.12 & 0.91 & 320 & 0.72 & 0.65 & 464 & 0.78 & 0.76 \\
\hline Psychoticism & 324 & 0.66 & 0.81 & 321 & 0.48 & 0.54 & 464 & 0.58 & 0.69 \\
\hline Total & 324 & 0.72 & 0.76 & 321 & 0.54 & 0.47 & 465 & 0.61 & 0.58 \\
\hline \multicolumn{10}{|l|}{ Adjustment II } \\
\hline \multirow{2}{*}{$\begin{array}{l}\text { Misconduct/Hostile (verbal/physical) } \\
\text { behavior in prison }\end{array}$} & $N$ & & & $N$ & & & $N$ & & \\
\hline & $($ total $N)$ & $\%$ & & $($ total $N)$ & $\%$ & & $($ total $N)$ & $\%$ & \\
\hline Towards fellow-detainee & $\begin{array}{l}34 \\
(327)\end{array}$ & 10.4 & & $\begin{array}{l}76 \\
(319)\end{array}$ & 23.8 & & $\begin{array}{l}189 \\
(476)\end{array}$ & 39.7 & \\
\hline Towards prison worker & $\begin{array}{l}11 \\
(324)\end{array}$ & 3.4 & & $\begin{array}{l}20 \\
(319)\end{array}$ & 6.2 & & $\begin{array}{l}49 \\
(476)\end{array}$ & 10.3 & \\
\hline
\end{tabular}

missing their own house $(\mathrm{t}(762)=-4.79, \quad p<0.000)$, missing their partner $(\mathrm{t}(756)=-7.74, p<0.000)$, and missing pets $(\mathrm{t}(758)=-2.84, p<0.000)$. Vice versa, nonfathers more severely missed money $(\mathrm{t}(755)=2.58, p<$ $0.000)$, their parents $(\mathrm{t}(764)=5.71, p<0.000)$, friends $(\mathrm{t}$ $(766)=2.98, p<0.000)$, and drugs $(\mathrm{t}(736)=4.67, p<$ 0.000). The fathers reported that they missed their children more than any other deprivation strain (see Fig. 1; mean score of 4.5 on a 5 -point scale).

At both waves, fathers and non-fathers did not differ with respect to mental health symptoms. When looking at the development of mental health symptoms over time, both
Deprivation strains of fathers and non-fathers

"To what extent do you miss.. " (score 0-5)

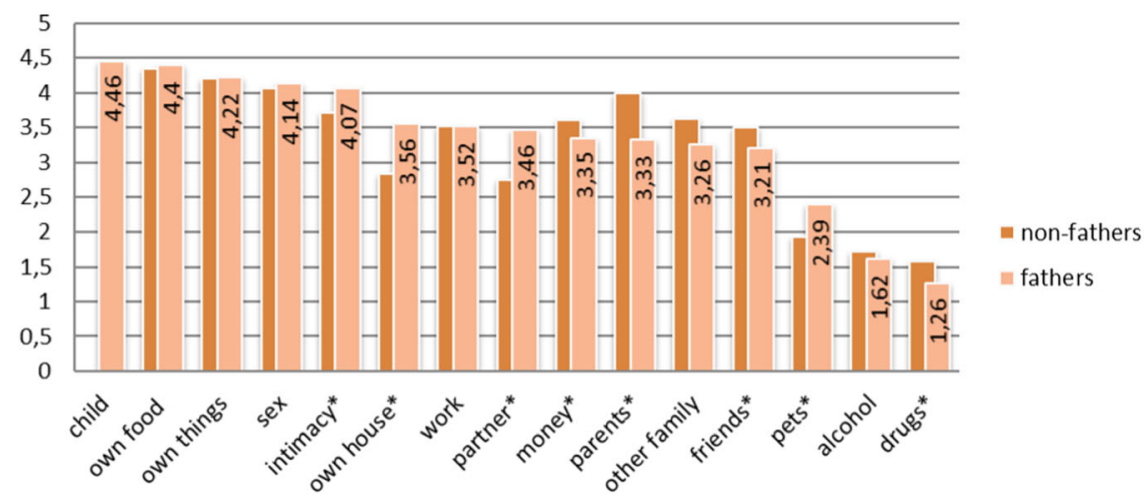


Table 3 Predictors of fathers and non-fathers' adjustment problems: total mental health (BSI) score

\begin{tabular}{|c|c|c|c|c|c|}
\hline & $\mathrm{B}$ & SE & $\beta$ & $\mathrm{t}$ & $p$ \\
\hline \multicolumn{6}{|l|}{ Regression 1} \\
\hline \multicolumn{6}{|c|}{$\begin{array}{l}\text { Fatherhood > adjustment problems I: total mental health (BSI) } \\
\text { score ( } 3 \text { months) }\end{array}$} \\
\hline (Constant) & 0.217 & 0.071 & & 3.067 & 0.002 \\
\hline Non-father/ father & -0.108 & 0.041 & -0.102 & -2.635 & 0.009 \\
\hline BSI total (3 weeks) & 0.352 & 0.024 & 0.491 & 14.906 & 0.000 \\
\hline Partner & 0.005 & 0.002 & 0.096 & 2.490 & 0.013 \\
\hline Age & 0.072 & 0.037 & 0.067 & 1.947 & 0.052 \\
\hline Ethnicity & 0.023 & 0.038 & 0.021 & 0.615 & 0.538 \\
\hline Job & -0.021 & 0.036 & -0.019 & -0.580 & 0.562 \\
\hline Education & -0.031 & 0.030 & -0.036 & -1.061 & 0.289 \\
\hline \multicolumn{6}{|l|}{ Regression 2} \\
\hline \multicolumn{6}{|c|}{$\begin{array}{l}\text { Fatherhood > adjustment problems II: misconduct in prison } \\
\text { towards fellow-detainees }\end{array}$} \\
\hline (Constant) & 0.615 & 0.069 & & 8.975 & 0.000 \\
\hline Non-father/ father & -0.053 & 0.041 & -0.056 & -1.307 & 0.192 \\
\hline Age & -0.009 & 0.002 & -0.202 & -4.712 & 0.000 \\
\hline Partner & 0.009 & 0.037 & 0.010 & 0.254 & 0.799 \\
\hline Ethnicity & -0.018 & 0.037 & -0.018 & -0.470 & 0.638 \\
\hline Job & -0.061 & 0.035 & -0.065 & -1.757 & 0.079 \\
\hline Education & 0.018 & 0.029 & 0.023 & 0.611 & 0.541 \\
\hline \multicolumn{6}{|l|}{ Regression 3} \\
\hline \multicolumn{6}{|c|}{$\begin{array}{l}\text { Fatherhood > adjustment problems II: misconduct in prison } \\
\text { towards prison workers }\end{array}$} \\
\hline (Constant) & 0.192 & 0.040 & & 4.771 & 0.000 \\
\hline Non-father/ father & 0.006 & 0.024 & 0.010 & 0.229 & 0.819 \\
\hline Age & -0.004 & 0.001 & -0.147 & -3.360 & 0.001 \\
\hline Partner & -0.014 & 0.022 & -0.025 & -0.639 & 0.523 \\
\hline Ethnicity & -0.025 & 0.022 & -0.045 & -1.155 & 0.248 \\
\hline Job & -0.030 & 0.021 & -0.055 & -1.462 & 0.144 \\
\hline Education & 0.020 & 0.017 & 0.044 & 1.146 & 0.252 \\
\hline
\end{tabular}

$B$ beta, $S E$ standard error, $\beta$ beta, $t$ t statistic, $p$ significance level

To answer research question three, we focused on the fathers and examined the effects of their deprivation strains on their subsequent mental distress (measured three months after their arrival in detention). Multivariate regression analyses (with control variables; partner, age, ethnicity, job, educational level) were conducted for all BSI scales. For two of 10 scales, significant associations were found. The degree to which fathers missed their children shortly after their arrival in detention significantly predicted the level of anxiety after three months $(\beta=$ $0.128, p<0.05$ ) (see Table 4). In a similar way, fathers who reported a higher degree to which they missed their children shortly after their arrival in detention, reported
Table 4 Fathers' deprivation strains and adjustment problems

B $\quad$ SE $\quad \beta \quad$ t $\quad p$

Regression 1

Missing children > adjustment problems: depressive behavior

$\begin{array}{lrrrrr}\text { (Constant) } & 0.305 & 0.253 & & 1.207 & 0.228 \\ \text { Missing children } & 0.086 & 0.035 & 0.138 & 2.467 & 0.014 \\ \text { Age } & 0.003 & 0.004 & 0.036 & 0.602 & 0.548 \\ \text { Partner } & 0.207 & 0.107 & 0.110 & 1.937 & 0.054 \\ \text { Ethnicity } & -0.291 & 0.102 & -0.166 & -2.850 & 0.005 \\ \text { Job } & -0.146 & 0.089 & -0.094 & -1.643 & 0.101 \\ \text { Educational level } & 0.034 & 0.067 & 0.029 & 0.499 & 0.618\end{array}$

Regression 2

Missing children > adjustment problems: anxiety

$\begin{array}{lrrrrr}\text { (Constant) } & 0.153 & 0.192 & & 0.795 & 0.427 \\ \text { Missing children } & 0.052 & 0.026 & 0.112 & 1.985 & 0.048 \\ \text { Age } & 0.003 & 0.003 & 0.062 & 1.038 & 0.300 \\ \text { Partner } & 0.107 & 0.081 & 0.075 & 1.310 & 0.191 \\ \text { Ethnicity } & -0.121 & 0.078 & -0.091 & -1.558 & 0.120 \\ \text { Job } & -0.171 & 0.068 & -0.146 & -2.534 & 0.012 \\ \text { Educational level } & 0.023 & 0.051 & 0.027 & 0.455 & 0.649\end{array}$

$B$ beta, $S E$ standard error, $\beta$ beta, $t$ t statistic, $p$ significance level

more depressive symptoms after three months $(\beta=0.158$, $p<0.005)$ (see Table 4).

\section{Discussion}

In this large, nationwide, prospective cohort study, Dutch incarcerated males were questioned 3 weeks after their arrival. Those still in custody were questioned again after 3 months. Both fathers and non-fathers reported on their experienced severity of detention and their development of adjustment problems. We collected comprehensive data on multiple adjustment problems, on a variety of demographic variables and 'pains of imprisonment' and we have included a range of potential confounding variables in the analyses. Moreover, because of longitudinal design of the study, we were able to report on the development of adjustment problems in both groups. The study revealed that fathers and non-fathers show differences in adjustment patterns in prison and experience different 'pains of imprisonment'. We found that father's unique deprivation strain of missing children causes anxiety and depressive problems during pretrial detention. Fathers and non-fathers were found to be different groups in the prison population: fathers in prison are generally older, higher educated and more often in a romantic relationship than non-fathers. Regarding their criminal patterns, we found that fewer fathers than 
non-fathers were convicted of a violent offense. Conversely, more fathers were convicted of drug-offenses than were non-fathers. These results suggest that fathers seem to be a more settled and well-functioning group of inmates, having partners and committing non-violent crimes. These positive characteristics of the father population may be relevant in an attempt to reconsider prison policies and reduce restrictions regarding communication and contact between detainees and their children. Initiating more contact possibilities between children and fathers in prison is primarily relevant because previous studies suggest that more parenting opportunity during incarceration generates less harm among children of incarcerated fathers and thus less intergenerational damage (Dennison et al. 2017). In addition, the results may be relevant knowledge for discussions about alternative sentencing of caring responsible fathers, to keep children and parents together.

Our results also point out that knowing whether a male detainee has or does not have children adds to predicting the inmate's adjustment problems. In general, we found no differences in hostile adjustment patterns between fathers and non-fathers. In addition, the longitudinal development of mental health problems was the same for fathers and nonfathers; both groups showed a decrease of mental health problems after three months, except for depressive problems. Moreover, fathers and non-fathers experience the same overall severity of pre-trial detention. However, fathers have less self-reported mental adjustment problems than non-fathers. In addition, fathers and non-fathers rank their experienced deprivation strains (no drugs, no parents, no partner, et cetera) differently. These findings are in line with studies showing different adjustment patterns between mothers and non-mothers in (Fogel and Martin 1992). In addition, our results support the idea that prisoners with family in the outside world benefit from a protective factor for adjustment problems and therefore have better prospects for returning home (Casey-Avecedo and Bakken 2002; Hairston 1991; Poehlmann et al. 2010). Possibly, the benefits and disadvantages of being a father largely nullify each other. That is, while non-fathers suffer from deprivation in terms of missing drugs and their parents, fathers suffer from the lack of seeing their children and partners.

Furthermore, we hypothesized that fathers might experience unique 'pains of imprisonment' that cause emotional or behavioral adjustment problems. Focusing on fathers in this study, we found that father's unique deprivation strains influence adjustment to prison life negatively. Similar to results of studies among mothers (Fogel 1993; Houck and Loper 2002), we found that if fathers miss their children, they more often suffer from mental distress. Fathers missing their child, reported to suffer from anxiety and depressive problems. Adjustment problems concerning misconduct were not found. This implicates that fathers show more emotional adjustment problems that behavioral adjustment problems. Previous studies have reported on emotional trauma among mothers as a result of the separation of their child via incarceration (Baldwin 2018). It is not unlikely that fathers experience similar emotional traumas, which might cause emotional problems such as anxiety and depressive problems, rather than hostile behavior. Future research is needed on this subject.

Psychological explanations for developing adjustment problems among incarcerated fathers may also lie in fatherhood-related cognitive shifts leading to depressive feelings, that is, the perception of losing father-identity while in prison (Paternoster and Bushway 2009; Doekhie et al. 2017). Fathers reported to rebuild self-esteem after first losing father-identity in prison and then learning a positive parenting attitude. In line with this, losing fatheridentity may result in negative adjustment problems (Purvis 2013). These explanations give reason to further study the development of father-identity in prison, not only because of its association with adjustments problems, but also because of the association between the loss of fatheridentity and recidivism (Paternoster and Bushway 2009; Doekhie et al. 2017).

Also, the results of this study are relevant within the context of proportional sentencing and prison policy. Regarding proportional sentencing, it is important for sentencers to know the unique pains of imprisonment of incarcerated parents and their significant unintended effects during pre-trial detention. Our results add to existing knowledge on this topic and provide evidence for the hypothesis that unique parent strains lead to more negative adjustment patterns (Arditti 2005; Magaletta and Herbst 2001; Poehlmann 2005; Fogel 1993; Hairston 1991; Houck and Loper 2002; Kruttschnitt and Gartner 2005). Proportional sentencing of fathers in the criminal justice system could only be substantiated as long as sufficient attention will be paid to their unique deprivation strain, which is, missing their children. Furthermore, the results of this study could also contribute to revisions of prison policies, that is, to considerations about priorities in prison-interventions. The results suggest that, to reduce adjustment problems during pre-trial detention, an even amount of attention must be paid to drug addictions as to father-child relationships. Fathering programs or parenting support programs, as described in prior studies (Bartlett 2019; Pierce 2015; Reef et al. 2018) could facilitate the connection between incarcerated fathers and children, and decrease unintended consequences of incarceration. The new knowledge that this study provides, emphasizes the importance of designing interventions for fathers in prison and educating sentencers about this topic. Care for the child-father relation may not only lead to father's emotional wellbeing during pre-trial detention, but may also to 
strengthened family bonds and children's wellbeing on the long term.

\section{Strengths and Limitations}

The present study has some methodological limitations. First, in this study, we used the BSI to measure prisoners' mental health problems. This instrument is a screening questionnaire, and not a clinician administered interview. Hence, the current study examines mental health symptoms, and not psychiatric disorders. Previous research did, however, show that the BSI is a reliable and valid screening instrument (De Beurs and Zitman 2006). Second, regarding generalizability of the results, we cannot be certain that our findings are evident for other correctional contexts. The present study was conducted in a correctional facility in the Netherlands. Although prison policies became more restrictive in the past years, the Netherlands still has a relatively short sentences and a mild sentencing climate (Dervan 2011). Third, to assess fatherhood, we asked respondents to complete a dichotomous survey question; "do you have children?". We obtained information on the males being a father, and not about the level of dependence of the child. In the current study we did not include information about the children (e.g, their age, their living situation, their level of dependence). Possibly, the impact of incarceration, and also adjustment patterns, differ between fathers with dependent children and fathers with independent children. We intend to address this issue in a future study.

The present study also has important strengths. First, it contributes to current knowledge on the experienced severity and adjustment in a relatively large representative national sample of both fathers and non-fathers. Second, regarding the fact that the global quantity of longitudinal studies examining experienced severity among incarcerated fathers is still limited, the present study has generated valuable information regarding adjustment of fathers during imprisonment, and their unique deprivation strains. The contribution to current knowledge on this issue is important because paternal imprisonment may disproportionately affect caring fathers, their children and families at large. Multiple generations of fragile families are negatively affected by incarceration, which forms an unintended, costly, and enduring burden to society. Furthermore, with this study, we answered the call of the Council of Europe for more research on incarcerated parents in their recommendation issued in April 2018 (Recommendation CM/Rec (2018)5). This study provides knowledge for a more sustainable and effective criminal justice system.

Author Contributions Both authors were involved in the design and execution of the study. J.R. conducted the analyses and wrote the draft of the paper. A.D. collaborated in writing and editing of the final manuscript.

\section{Compliance with Ethical Standards}

Conflict of Interest The authors declare that they have no conflict of interest.

Ethical Approval The study protocol was submitted to and reviewed positively by the Ethical Committee for Legal and Criminological Research of the VU University Amsterdam.

Informed Consent Informed consent was obtained from all individual participants included in the study.

Publisher's note Springer Nature remains neutral with regard to jurisdictional claims in published maps and institutional affiliations.

Open Access This article is distributed under the terms of the Creative Commons Attribution 4.0 International License (http://crea tivecommons.org/licenses/by/4.0/), which permits unrestricted use, distribution, and reproduction in any medium, provided you give appropriate credit to the original author(s) and the source, provide a link to the Creative Commons license, and indicate if changes were made.

\section{References}

Apel, R., Blokland, A. A. J., Nieuwbeerta, P., \& van Schellen, M. (2010). The impact of imprisonment on marriage and divorce: a risk set matching approach. Journal of Quantitative Criminology, 26(2), 269-300.

Arditti, J. A. (2003). Locked doors and glass walls: family visiting at a local jail. Journal of Loss \& Trauma, 8(2), 115-138.

Arditti, J. A. (2005). Families and incarceration: an ecological approach. Families in Society-the Journal of Contemporary Social Services, 86(2), 251-260.

Baldwin, L. (2018). Motherhood disrupted: reflections of post-prison mothers. Emotion, Space, and Society, 26, 49-56.

Baldwin, L., \& Epstein, R. (2017). Short but not sweet: a study of the impact of short custodial sentences on mothers and their children. Leicester: De Montfort University.

Banauch, P. J. (1985). Mothers in prison. New Brunswick, NJ: Transaction Books.

Bartlett, T. S. (2019). Supporting incarcerated fathers: an exploration of research and practice in Victoria, Australia. Probation Journal, 66(2), 201-218.

Bartlett, T. S., \& Eriksson, A. (2019). How fathers construct and perform masculinity in a liminal prison space. Punishment and Society, 21(3), 275-294.

Bartlett, T. S., Flynn, C. A., \& Trotter, C. J. (2018). “They didn't even let me say goodbye": a study of imprisoned primary carer fathers' care planning for children at the point of arrest in Victoria, Australia. Child Care in Practice, 24(2), 115-130.

Bartlett, T., \& Trotter, C. (2019). Did we forget something? Fathering supports and programs in prisons in Victoria, Australia. International Journal of Offender Therapy and Comparative Criminology, 63(8), 1465-1481.

Beckerman, A. (1989). Incarcerated mothers and their children in foster care: the dilemma of visitation. Children and Youth Services Review, 11, 175-183. 
Brodsky, S. L. (1995). Living in prison - the ecology of survival. Contemporary Psychology, 40(6), 551-552.

Brown, K., Dibb, L., Shenton, F., \& Elson, N. (2001). No one's ever asked me: young people with a prisoner in the family. London: Action for Prisoners' Families.

Brownell, P. (1997). Female offenders in the criminal justice system: policy and program development. In R. Roberts (Ed.), Social work in juvenile and criminal justice settings. 2nd ed. (pp. 235-349). Springfield, IL: Charles C. Thomas.

Burgess, A., \& Flynn, C. (2013). Supporting imprisoned mothers and their children: a call for evidence. Probation Journal, 60(1), 73-81.

Casey-Avecedo, K., \& Bakken, T. (2002). Visiting women in prison: who visits and who cares. Journal of Offender Rehabilitation, 34, 67-83.

Coley, R. L., \& Coltrane, S. (2007). Commentary: impact of father involvement on children's developmental trajectories: new findings panel for the national fatherhood forum. Applied Developmental Science, 11(4), 226-228.

Coll, C. G, Surrey, J. L, Buccio-Notaro, P., \& Molla, B. (1998). Incarcerated mothers: crimes and punishments. In C. G. Coll, J. L. Surrey, E. Weingarten, (Eds.), Mothering against the odds: diverse voices of contemporary mothers (pp. 255-274). New York: Guilford.

Council of Europe (2018). Recommendation CM/Rec(2018)5 of the Committee of Ministers to member states concerning children with imprisoned parents. Strasbourg, France: Author.

Dallaire, D. H. (2007). Incarcerated mothers and fathers: a comparison of risk for children and families. Family Relations, 56, 440-453.

De Beurs, E., \& Zitman, F. (2006). De brief symptom inventory (BSI): betrouwbaarheid en validiteit van een handzaam alternatief voor de SCL-90. Maandblad Geestelijke Volksgezondheid, 61(2), 120-141.

Dennison, S., Smallbone, H., \& Occhipinti, S. (2017). Understanding how incarceration challenges proximal processes in father-child relationships: perspectives of imprisoned fathers. Journal of Developmental and Life-Course Criminology, 3(1), 15-38.

Dennison, S., Smallbone, H., Stewart, A., Freiberg, K., \& Teague, R. (2014). 'My life is separated': an examination of the challenges and barriers to parenting for Indigenous fathers in prison. British Journal of Criminology, 54(1), 1089-1108.

Dennison, S., Stewart, A., \& Freiberg, K. (2013). A prevalence study of children with imprisoned fathers: annual and lifetime estimates. Australian Journal of Social Issues, 48(3), 339-362.

Derogatis, L. (1993). Brief Symptom Inventory (BSI): Administration, scoring, and procedures manual. 3rd ed. Minneapolis, MN: National Computer Systems.

Dervan, L. E. (2011). American prison culture in an international context: an examination of prisons in America, The Netherlands and Israel. Stanford Law \& Policy Review, 22(2), 413-428.

Dirkzwager, A. J. E., \& Nieuwbeerta, P. (2018). Mental health symptoms during imprisonment: a longitudinal study. Acta Psychiatrica Scandinavica, 138(4), 300-311.

Dirkzwager, A. J. E., Nieuwbeerta, P., Beijersbergen, K. A., Bosma, A. Q., De Cuyper, R., Doekhie, J., \& Wermink, H. (2018). Cohort profile: the prison project - a study of criminal behavior and life circumstances before, during and after imprisonment in the Netherlands. Journal of Developmental and Life-Course Criminology, 4(1), 120-135.

Dirkzwager, A. J. E., Nieuwbeerta, P., \& Fiselier, J. P. S. (2009). Onbedoelde gevolgen van vrijheidsstraffen. Een literatuurstudie. Tijdschrift voor Criminologie, 51, 21-41.

Doekhi, J., Dirkzwager, A. J. E., \& Nieuwbeerta, P. (2017). Early attempts at desistance from crime: prisoners' prerelease expectations and their postrelease criminal behavior. Journal of Offender Rehabilitation, 56(7), 473-493.
Dodge, M., \& Pogrebin, M. R. (2001). Collateral costs of imprisonment for women: complications of reintegration. Prison Journal, $81,42-54$.

Dyer, W. J. (2005). Prison, fathers, and identity: a theory of how incarceration affects men's paternal identity. Fathering, 3(3), 201-219.

Enos, S. (1997). Managing motherhood in prison: the impact of race and ethnicity on child placements. Women and Therapy, 20, $57-73$.

Flynn, C. (2014). Getting there and being there: visits to prisons in Victoria - the experiences of women prisoners and their children. Probation Journal, 61(2), 176-191.

Fogel, C. I. (1993). Hard time: the stressful nature of incarceration for women. Issues in Mental Health Nursing, 14, 367-377.

Fogel, C. I., \& Martin, S. L. (1992). The mental health of incarcerated women. Western Journal of Nursing Research, 14, 30-47.

Fonagy, P., Steele, M., Steele, H., Higgitt, A., \& Target, M. (1994). The Emanuel Miller Memorial Lecture 1992. the theory and practice of resilience. Journal of Child Psychology and Psychiatry, 35(2), 231-257.

Glaze, L. E., \& Maruschak, L. M. (2008). Parents in prison and their minor children. Washington: Bureau of Justice Statistics.

Geller, A., Cooper, C. E., Garfinkel, I., Schwartz-Soicher, O., \& Mincy, R. B. (2012). Beyond absenteeism: father incarceration and child development. Demography, 49(1), 49-76.

Hairston, C. F. (1991). Family ties during imprisonment: Important to whom and for what? Journal of Sociology and Social Welfare, 87, 87-104.

Henriques, Z. W. (1982). Imprisoned mothers and their children: a descriptive and analytic study. Washington, DC: University Press of America.

Houck, K. D., \& Loper, A. B. (2002). The relationship of parenting stress to adjustment among mothers in prison. American Journal of Orthopsychiatry, 72, 548-558.

Hurley, W., \& Dunne, M. (1991). Psychological distress and psychiatric morbidity in women prisoners. Australia and New Zealand Journal of Psychiatry, 25, 461-470.

Johnston, D., \& Gabel, K. (1995). Incarcerated parents. In K. Gabel \& D. Johnston (Eds.), Children of incarcerated parents (pp. 3-20). New York, US: Lexington Books.

Kruttschnitt, C., \& Gartner, R. (2005). Marking time in the golden state: women's imprisonment in California. Cambridge, UK: Cambridge University Press.

Lanskey, C., Losel, F., Markson, L., \& Souza, K. (2016). Children's contact with their imprisoned fathers and the father-child relationship following release. Families, Relationships and Societies, 5(1), 43-58.

Lindquist, C. H. (2000). Social integration and mental well-being among jail inmates. Sociological Forum, 15(3), 431-455.

Lindquist, C. H., \& Lindquist, C. A. (1997). Gender differences in distress: mental health consequences of environmental stress among jail inmates. Behavioral Sciences and the Law, 15, 503-523.

Loper, A. B. (2006). How do mothers in prison differ from nonmothers? Journal of Child \& Family Studies, 15(1), 83-95.

Lopoo, L. M., \& Western, B. (2005). Incarceration and the formation and stability of marital unions. Journal of Marriage and Family, 67(3), 721-734.

Magaletta, P. R., \& Herbst, D. P. (2001). Fathering from prison: common struggles and successful solutions. Psychotherapy: Theory, Research, Practice, Training, 38, 88-96.

Minson, S. (2017). Who cares? Analysing the place of children in maternal sentencing decisions in England and Wales (doctoral thesis). Oxford, United Kingdom: University of Oxford.

Minson, S. (2018). The sins and traumas of fathers and mothers should not be visited on their children. The rights of children when a 
primary carer is sentenced to imprisonment in the criminal courts. In P. Smith \& R. Condry (Eds.), Prisons, punishment, and the family. Towards a new sociology of punishment? (pp. 136-150). Oxford: Oxford University Press.

Mumola, C. (2000). Incarcerated parents and their children. Washington, DC: US Department of Justice Office of Justice Programs.

Murray, J., \& Farrington, D. P. (2005). Parental imprisonment: effects on boys' antisocial behaviour and delinquency through the lifecourse. Journal of Child Psychology and Psychiatry, 46(12), $1269-1278$.

Nurse, A. M. (2009). Doing time together: love and family in the shadow of the prison. American Journal of Sociology, 115(3), 960-962.

Paternoster, R., \& Bushway, S. (2009). Desistance and the feared self: toward an identity theory of criminal desistance. Journal of Criminal Law and Criminology, 99, 1103-1156.

Phillips, S. D., Burns, B. J., Wagner, H. R., Kramer, T. L., \& Robbins, J. M. (2002). Parental incarceration among adolescents receiving mental health services. Journal of Child and Family Studies, 11 (4), 385-399.

Pierce, M. B. (2015). Male inmate perceptions of the visitation experience: suggestions on how prisons can promote inmatefamily relationships. The Prison Journal, 95(3), 370-396.

Poehlmann, J. (2005). Incarcerated mothers' contact with children, perceived family relationships, and depressive symptoms. Journal of the Division of Family Psychology of the American Psychological Association, 19, 350-357.
Poehlmann, J., Dallaire, D., Loper, A. B., \& Shear, L. D. (2010). Children's contact with their incarcerated parents research findings and recommendations. American Psychologist, 65(6), $575-598$.

Purvis, M. (2013). Paternal incarceration and parenting programs in prison: a review paper. Psychiatry, Psychology and Law, 20(1), 9-28.

Reef, J., \& Nieuwbeerta, P. (2016). De persoon van de verdachte vader: gezinsomstandigheden van Nederlandse verdachte vaders. Sancties, 31(4), 201-210.

Reef, J., Ormskerk, N., \& Es, Lvan (2018). Aandacht voor vaderschap in de gevangenis: evaluatie van de Exodus-workshop Vrij verantwoord vaderschap. Proces, Tijdschrift voor strafrechtspleging, 97(3), 216-227.

Scharff-Smith, P. (2014). When the innocent are punished. The children of imprisoned parents. New York: Palgrave Macmillan.

Scharff-Smith, P. (2018). Prisoners' families, public opinion, and the state: punishment and society from a family and human rights perspective. In: P. Smith, R. Condry (Eds.), Prisons, punishment, and the family. Towards a new sociology of punishment? (pp. 121-136). Oxford: Oxford University Press.

Seymour, C. B. (1998). Children with parents in prison: child welfare policy, program, and practice issues. Child Welfare, 77(5), 469-493.

Western, B., Lopoo, L. M., \& McLanahan, S. (2004). Incarceration and the bonds between parents in fragile families. In D. W. M. Pattillo \& B. Western (Eds.), Imprisoning America (pp. 21-45). New York: Russell Sage Foundation. 